\title{
Ingestion of macroplastics by common dolphinfish (Coryphaena hippurus) in the Atlantic Ocean
}

\author{
Eudriano F.S. Costa ${ }^{1, *}$, June Ferraz Dias ${ }^{2} @$, Lauro Antônio Saint Pastous Madureira ${ }^{3}(0$ \\ ${ }^{1}$ Centre of Marine Sciences (CCMAR), University of Algarve (Campus de Gambelas, 8005-139 Faro, Portugal) \\ ${ }^{2}$ Universidade de São Paulo - Instituto Oceanográfico (Praça do Oceanográfico - 191 - Butantã - 05508-900 - São Paulo - SP - Brazil) \\ ${ }^{3}$ Universidade Federal do Rio Grande - Instituto de Oceanografia (km 8 900, Av. Itália - Carreiros, Rio Grande - $96203-900$ - RS - Brazil) \\ *Corresponding author: eudrianocosta@gmail.com
}

The anthropogenic impact of pollution by plastic debris has threatened marine life inhabiting benthic and pelagic habitats from the poles to the equator (e.g., Ryan and Moloney, 1993; Derraik, 2002; Thompson et al., 2004). The ingestion of plastics by marine organisms is an increasing global trend due to the increase of these polymers in the oceans (e.g., Lusher et al., 2013; Besseling et al., 2015; Lusher et al., 2015; Lusher et al., 2018; Ostle et al., 2019; Neto et al., 2020). After reaching marine ecosystems, plastics can be found either in their large original size (i.e., macroplastic) or in small fragments (i.e., nanoplastics, microplastics, or mesoplastics) (Azevedo-Santos et al., 2019). Thus, the interaction of plastic debris with marine life is expected, and their ingestion has been documented in a wide range of marine organisms, including zooplankton, bivalves, fish, turtles, birds, and marine mammals (Azzarello and Van-Vleet, 1987; Lusher et al., 2015; Romero et al., 2015; Egbeocha et al., 2018). There are several possible reasons for the consumption of plastic debris by marine fish, including mistaking plastic for food because the odor of plastic in the sea is like that of food (Savoca et al., 2017), confusing it with prey species associated with floating plastic material while feeding on them, and preying on smaller organisms that have previously ingested plastics (Possato et al., 2011; Varghese et al., 2013).

Submitted: 09-Aug-2020

Approved: 12-March-2021

Editor: Rubens M. Lopes

(c) 2021 The authors. This is an open access article distributed under the terms of the Creative Commons license.
Records of fish ingesting plastic have increased in scientific literature because of concerns that the ingestion of anthropogenic debris by fish may, in turn, impact human health (Seltenrish, 2015; Lusher et al., 2015; Lusher et al., 2017; Azevedo-Santos et al., 2019). Plastic debris has a direct effect on fish, including the reduction in food uptake, internal abrasion and ulceration, diminished feeding stimulus, reproduction failure, and death following intestinal tract blockage (e.g., Azzarello and Van-Vleet, 1987; Ostle et al., 2019). From an ecological point of view, the ingestion of plastic debris is a route of entry for and potential cause of the biomagnification of toxic chemicals in the marine food web (Egbeocha et al., 2018). However, the environmental consequences of this contamination and the overall impact of plastic ingestion are still unknown, despite the growing number of publications on their presence in marine ecosystems and their ingestion by fish (e.g., Ryan and Moloney, 1993; Thompson et al., 2004; Gago et al., 2020, Neto et al., 2020). However, large pelagic fish, which are widely consumed by humans, show a presence of plastic debris that have the potential to indirectly affect human health (Romero et al., 2015).

The common dolphinfish, Coryphaena hippurus Linnaeus, 1758 (Perciformes, Coryphaenidae), is fished in an important commercial and recreational fishery and is widely distributed in tropical and subtropical waters in which the surface water temperatures exceed $20^{\circ} \mathrm{C}$ (Gibbs and Collete, 1959). Top-level predators, such as the common dolphinfish, can account for substantial levels of tertiary production 
being removed from an ecosystem, therefore play an important role in the trophic structure (Olson and Galván-Magaña, 2002; Varghese et al., 2013). Since this species is commonly associated with floating offshore objects, for example, fish aggregating devices or floating beds of Sargassum spp., it is an easy target for fisheries worldwide (Manooch et al., 1984; Massutí, et al., 1998; Rudershausen et al., 2010; Brewton et al., 2016). This study is the first to report on the largest macroplastic debris found in the stomach of the common dolphinfish, C. hippurus in the Southwest Atlantic Ocean.

A specimen of common dolphinfish, Coryphaena hippurus, was caught during an oceanography survey carried out in the Southwest Atlantic Ocean in 2012. The specimen was captured during the day (approximately 1 p.m.) by hook and line gear using artificial bait. The site was located $338 \mathrm{~km}$ off the coast of the city of Rio de Janeiro $\left(-23^{\circ} 59^{\prime} 8.94 \mathrm{~S}^{\prime \prime},-40^{\circ} 4^{\prime} 47.46 \mathrm{~W}^{\prime \prime}\right)$ in oceanic waters ( $>2,500 \mathrm{~m}$ depth). In the laboratory, the common dolphinfish was measured in total length (from the top of the snout to the end of the caudal fin), weighed, and dissected. The stomach contents were extracted with the help of scissors and forceps, placed in a petri dish for visual examination, and photographed with a digital camera. The plastic debris was easily identified due to its large size, color (black), brightness, and type (flexible synthetic material). The measurement of plastic material and prey items (i.e., fish larvae) was carried out using the software ImageJ (Rueden et al., 2017). The classification of the plastic debris into mesoplastic $(5 \mathrm{~mm}-25 \mathrm{~mm}$ ) and macroplastics ( $>25 \mathrm{~mm}$ ) was completed according to Rodrigo-Seijo and Pereira (2017).
The common dolphinfish measured $99.8 \mathrm{~cm}$ and weighed $4 \mathrm{~kg}$. Two pieces of macroplastic debris, a bottle label and piece of a plastic bag, were found. The former measured $7.4 \mathrm{~cm}$ in length and $51.3 \mathrm{~cm}^{2}$ in area, whereas the latter measured $11.8 \mathrm{~cm}$ with an area of $105.6 \mathrm{~cm}^{2}$. Along with the macroplastics, fish larvae, nematodes, and other unidentified parasites have been recorded (Fig. 1). Prey items ingested (i.e., fish larvae, Fig. 1A), ranged from 1.7 to $4.8 \mathrm{~cm}$ with mean and standard deviation of 2.42 and 0.92 , respectively. The size of the plastic debris found was much larger than that of the ingested food. Along with the macroplastics, nematodes and other unidentified parasites were recorded (Fig. 1C).

Plastic debris has been reported worldwide in the stomachs of the common dolphinfish. For instance, pieces of plastic bags, a plastic bowl, pieces of rope, polyethylene sheets, wrappers, bottle caps, plastic ribbons, and even a badminton shuttlecock have been found in dolphinfish from the Pacific Ocean to the Indian Ocean (Manooch et al., 1983; Massutí et al., 1998; Vaske Junior and Lessa, 2004; Rudeershausen et al., 2010; Vanghese et al., 2013; Choy and Drazen, 2013; Brewton et al., 2016; Menezes et al., 2019). This large epipelagic species is known to be a voracious top predator, feeding on a wide range of pelagic and demersal organisms, including cephalopods, crustaceans, and several fish belonging to the Carangidae, Balistidae, Tetraodontidae, Exocoetidae, and Scombridae families (Massutí, et al., 1998; Carbonell et al., 1999; Varghese et al., 2013; Brewton et al., 2016). This ingestion of a wide range of prey, which has been associated with the dolphinfish's opportunistic, voracious feeding nature, can increase the
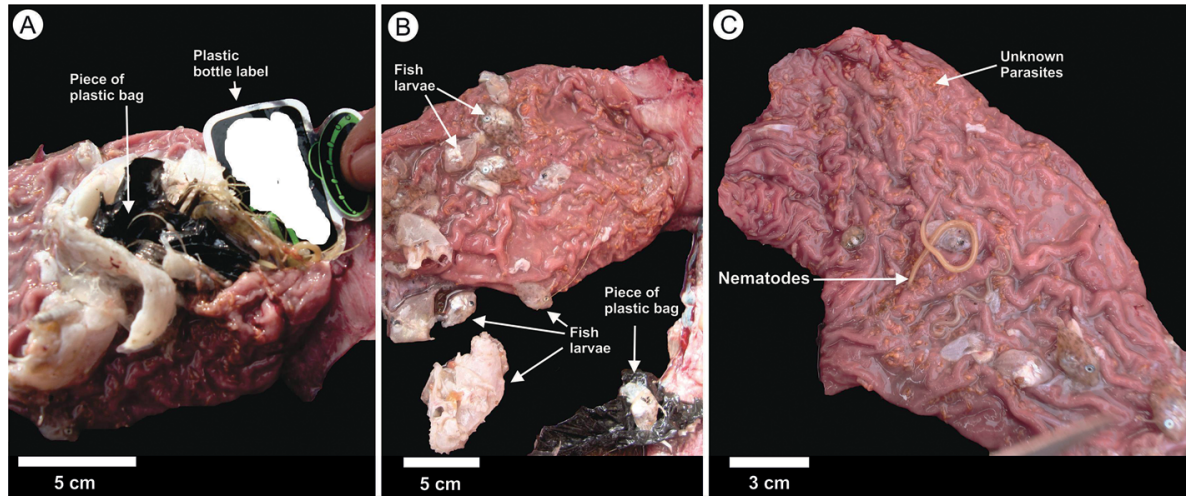

Figure 1. Records of macroplastic debris in the stomach of the common dolphinfish, Coryphaena hippurus. A- full stomach showing a piece of black plastic bag and a bottle label, B- ingestion of fish larvae, and C- occurrence of parasites. 
probability of the passive intake of plastic through prey (i.e., secondary ingestion), especially in large predatory fish such as the dolphinfish (Massutí et al., 1998; Varghese et al., 2013; Alomar et al., 2017; Neto et al., 2020). Thus, few studies have reported on macroplastic debris found in the stomachs of common dolphinfish on a global scale (Monooch et al., 1983; Mussuti et al., 1998; Vaske-Junior and Lessa, 2004; Rudershausen et al., 2010; Varghese et al., 2013; Choy et al., 2013; Brewton et al., 2016; Menezes et al., 2019). These studies were carried out between 1984 and 2011, and most of the specimens were sampled from along the Atlantic Coast of the United States (Fig. 2). However, occurrences of macroplastics in the stomachs of common dolphinfish have only been reported in the last ten years (Menezes et al., 2019).

A plastic bowl with an area of $99.57 \mathrm{~cm}^{2}$ was found in a specimen of common dolphinfish caught in the western equatorial Atlantic in 2011 (Menezes et al., 2019). These authors claimed that this piece of plastic material was the largest ever found in the stomach of that species, but the piece of plastic bag found in the specimen caught for this present study was slightly larger $\left(105.6 \mathrm{~cm}^{2}\right)$. Menezes et al. (2019) noted that the absence of common prey in its stomach was due to the large size of the macroplastic bowl, which made it difficult for the specimen to ingest new prey by blocking the digestive tract. In this current study, the presence of intact prey may indicate the recent ingestion of fish larvae, even with the presence of macroplastics in the stomach. The macroplastics were likely accidentally ingested after the ingestion of this prey during the peak of intensity of the feeding activity because the bottle label and the piece of plastic bag were much larger than the larvae and were positioned in the anterior portion of the stomach, which could block the ingestion of new food. According to Egbeocha et al. (2018), the obstruction and blockage of the digestive tract could result in a false feeling of satiation, which could thus lead to starvation and physical deterioration, ultimately leading to death. This supports the idea that the macroplastics were the last items ingested by the common dolphinfish.

The presence of parasites and macroplastics in the stomach of a common dolphinfish was recorded in this current study. Although the identification of these parasites to the species level was not possible, the nematodes and the specimen identified as unknown were probably two endogastric parasites of the genus Hysterothylacium sp. (nematoda) and Dinurus sp. (trematoda), which are considered endemic to the common dolphinfish (Brewton et al., 2016). These parasites usually have a high rate of infection and have been found in common dolphinfish caught in the Mediterranean, the Gulf of Mexico, the Atlantic Coast of the United States, the Southwest Atlantic Ocean, and the Pacific Ocean (Manooch et al., 1983; Carbonell et al., 1999; Marque and Alves, 2011; Brewton et al., 2016).

This study is the first to find macroplastic debris in the stomach of common dolphinfish caught in the Southwest Atlantic Ocean. It also documents the presence of recent food, endogastric parasites, and the largest plastic material ingested by this species ever recorded. It is important to highlight that the common dolphinfish is a top predator that plays an important role in the marine food web, and plastic trophic transfer may therefore have a number of

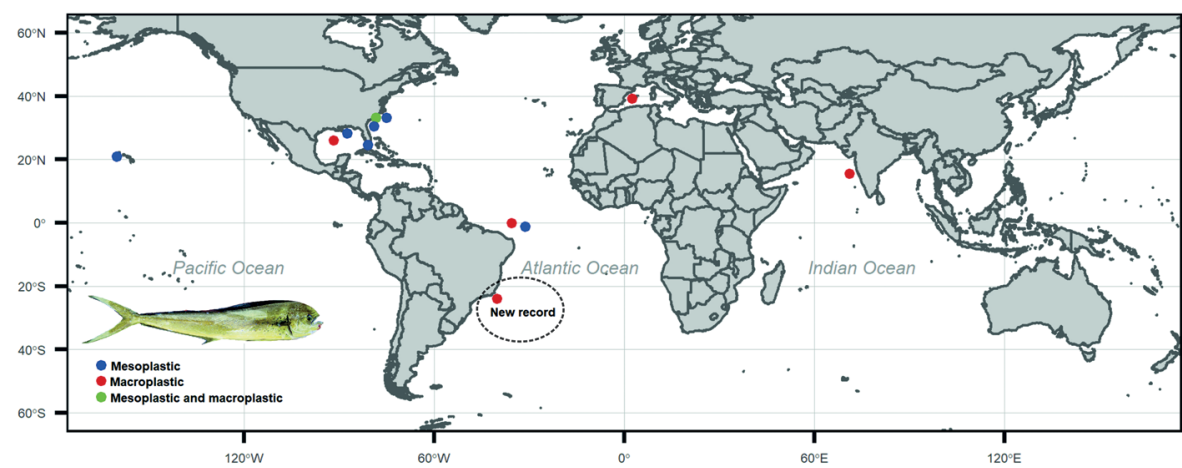

Figure 2. Map showing global records of plastic debris in the stomach of the common dolphinfish, Coryphaena hippurus, and the new record for Southwest Atlantic Ocean. 
implications for species, ecosystems, and human health (Nelms et al., 2018).

\section{ACKNOWLEDGMENTS}

The authors are grateful to the crew of the Atlântico Sul, the FURG's research vessel, for catching the studied specimen and the Institute of Oceanography of the University of São Paulo (IOUSP) for their support during the oceanographic cruise. This study was financed in part by a doctorate scholarship (grant number 7,546/13-0) from the Coordination of Improvement of Higher Education Personnel-Brazil (CAPES). The authors would also like to thank two anonymous reviewers for their constructive comments, which have helped us improve the quality of the manuscript.

\section{AUTHOR CONTRIBUTIONS}

E. F. S. C.: Investigation; Conceptualization; Methodology; Writing - original draft; Writing - review \& editing.

J. F. D.: Supervision; Writing - review \& editing; Funding acquisition.

L. A. S. P. M.: Supervision; Writing - review \& editing; Funding acquisition.

\section{REFERENCES}

ALOMAR, C., SUREDAB, A., CAPÓ, X., GUIJARRO, B., TEJADA, S. \& DEUDERO, S. 2017. Microplastic ingestion by Mullus surmuletus Linnaeus, 1758 fish and its potential for causing oxidative stress. Environmental Research, 159, 135-142.

AZEVEDO-SANTOS, V. M., GONÇALVES, G. R. L., MANOEL, P. S., ANDRADE, M. C., LIMA, F. P. \& PELICICE, F. M. 2019. Plastic ingestion by fish: a global assessment. Environmental Pollution, 255(Pt 1), 112994.

AZZARELLO, M. Y. \& VAN-VLEET, E. S. 1987. Marine birds and plastic pollution. Marine Ecology Progress Series, 37, 295-303.

BESSELING, E., FOEKEMA, E. M., VAN FRANEKER, J. A., LEOPOLD, M. F., KÜHN, S., REBOLLEDO, E. L. B., HEBE, E., MIELKE, L., IJZER, J., KAMMING, P. \& KOELMANS, A. A. 2015. Microplastic in a macro filter feeder: humpback whale Megaptera novaeangliae. Marine Pollution Bulletin, 95(1), 248-252.

BREWTON, R. A., AJEMIAN, M. J., YOUNG, P. C. \& STUNZ, G. W. 2016. Feeding ecology of dolphinfsh in the Western Gulf of Mexico. Transactions of the American Fisheries Society, 145(4), 839-853.

CARBONELL, E., MASSUTÍ, E., CASTRO, J. J. \& GARCÍA, R. M. 1999. Parasitism of dolphinfishes, Coryphaena hippurus and Coryphaena equiselis, in the western Mediterranean (Balearic Islands) and central-eastern Atlantic (Canary Islands). Scientia Marina, 63(3), 343-354.

CHOY, C. A. \& DRAZEN, J. C. 2013. Plastic for dinner? Observations of frequent debris ingestion by pelagic predatory fishes from the central North Pacific. Marine Ecology Progress Series, 485, 155-163.
DERRAIK, J. G. B. 2002. The pollution of the marine environment by plastic debris: a review. Marine Pollution Bulletin, 44(9), 842-852.

EGBEOCHA, C. O., MALEK, S., EMENIKE, C. U. \& MILOW, P. 2018. Feasting on microplastics: ingestion by and effects on marine organisms. Aquatic Biology, 27, 93-106.

GAGO, J., PORTELA, S., FILGUEIRAS, A. V., SALINAS, M. P. \& MACÍAS, D. 2020. Ingestion of plastic debris (macro and micro) by longnose lancetfish (Alepisaurus ferox) in the North Atlantic Ocean. Regional Studies in Marine Sciences, 33, 100977.

GIBBS JUNIOR, R. H. \& COLLETTE, B. B. 1959. On the identification, distribution, and biology of the dolphins, Coryphaena hippurus and C. equiselis. Bulletin of Marine Science, 9(2), 117-152.

LUSHER, A. L., HERNANDEZ-MILIAN, G., BERROW, S., ROGAN, E. \& O'CONNOR, I. 2018. Incidence of marine debris in cetaceans stranded and bycaught in Ireland: Recent findings and a review of historical knowledge. Environmental Pollution, 232, 467-746.

LUSHER, A. L., HERNANDEZ-MILIAN, G., O'BRIEN, J., BERROW, S., O'CONNOR, I. \& OFFICER, R. 2015. Microplastic and macroplastic ingestion by a deep diving, oceanic cetacean: the true's beaked whale Mesoplodon mirus. Environmental Pollution, 199, 185-191.

LUSHER, A. L., HOLLMAN, P. C. H. \& MENDOZA-HILL, J. J. 2017. Microplastics in fisheries and aquaculture: status of knowledge on their occurrence and implications for aquatic organisms and food safety. Rome: FAO (Food and Agriculture Organization of the United Nations).

LUSHER, A. L., MCHUGH, M. \& THOMPSON, R. C. 2013. Occurrence of microplastics in the gastrointestinal tract of pelagic and demersal fish from the English Channel. Marine Pollution Bulletin, 67(1-2), 94-99.

MANOOCH, C. S., MASON, D. L. \& NELSON, R. S. 1984. Food and gastrointestinal parasites of dolphin Coryphaena hippurus collected along the southeastern and Gulf Coasts of the United States. Bulletin of the Japanese Society of Scientific Fisheries, 50(9), 1511-1525.

MARQUES, L. C. \& ALVES, D. R. 2011. Community ecology of the metazoan parasites of common dolphinfish Coryphaena hippurus Linnaeus, 1758 (Osteichthyes: Coryphaenidae) from the coastal zone State of Rio de Janeiro, Brazil. Cadernos UniFOA, 6(16), 111-122.

MASSUTÍ, E., DEUDERO, S., SÁNCHEZ, P. \& MORALES-NIN, B. 1998. Diet and feeding of dolphin (Coryphaena hippurus) in western Mediterranean waters. Bulletin of Marine Science, 63(2), 329-341.

MENEZES, R., CUNHA-NETO, M. A., MESQUITA, G. C. \& SILVA, G. B. 2019. Ingestion of macroplastic debris by the common dolphinfish (Coryphaena hippurus) in Western Equatorial Atlantic. Marine Pollution Bulletin, 141, 161-163.

NETO, J. G. B., RODRIGUES, F. L., ORTEGA, I., RODRIGUES, L. S., LACERDA, A. L. D. F., COLLETO, J. L., KESSLER, F., CARDOSO, L. G., MADUREIRA, L., PROIETTI, M. C. 2020. Ingestion of plastic debris by commercially important marine fish in southeastsouth Brazil. Environmental Pollution, 267, 115508.

OLSON, R. J. \& GALVÁN-MAGAÑA, F. 2002. Food habits and consumption rates of common dolphinfish (Coryphaena hippurus) in the eastern Pacific Ocean. Fishery Bulletin. $100(2), 279-298$ 
OSTLE, C., THOMPSON, R. C., BROUGHTON, D., GREGORY, L., WOOTTON, M. \& JOHNS, D. G. 2019. The rise in ocean plastics evidenced from a 60-year time series. Nature Communications, 10(1), 1622.

POSSATO, F., BARLETTA, M., COSTA, M., IVAR DO SUL, J. \& DANTAS, D. V. 2011. Plastic debris ingestion by marine catfish: an unexpected fisheries impact. Marine Pollution Bulletin, 62(5), 1098-1102.

RODRÍGUEZ-SEIJO, A. \& PEREIRA, R. 2017. Morphological and physical characterization of microplastics. Comprehensive Analytical Chemistry, 75, 49-66.

ROMEO, T., PIETRO, B., PEDÁ, C., CONSOLI, P., ANDALORO, F. \& FOSSI, M. C. 2015. First evidence of presence of plastic debris in stomach of large pelagic fish in the Mediterranean Sea. Marine Pollution Bulletin, 95(1), 358-361.

RUDERSHAUSEN, P. J., BUCKEL, J. A., EDWARDS, J., GANNON, D. P., BUTLER, C. M. \& AVERETT, T. W. 2010. Feeding ecology of blue marlins, dolphinfish, yellowfin tuna, and Wahoos from the North Atlantic Ocean and comparisons with other oceans. Transactions of the American Fisheries Society, 139(5), 1335-1359.

RUEDEN, C. T., SCHINDELIN, J., HINER, M. C., DEZONIA, B. E., WALTER, A. E., ARENA, E. T. \& ELICEIRI, K. W. 2017. ImageJ2: ImageJ for the next generation of scientific image data. BMC Bioinformatics, 18(1), 529.
RYAN, P. G. \& MOLONEY, C. L. 1993. Marine litter keeps increasing. Nature, 361, 23.

SAVOCA, M. S., TYSON, C. W., MCGILL, M. \& SLAGER, C. J. 2017. Odours from marine plastic debris induce food search behaviours in a forage fish. Procedings of the Royal Society $B$, 284(1860), 20171000.

SELTENRICH, N. 2015. New link in the food chain? Marine plastic pollution and seafood safety. Environmental Health Perspectives, 123(2), A34-A41.

THOMPSON, R. C., OLSEN, Y., MITCHELL, R. P., DAVIS, A., ROWLAND, S. J., JOHN, A. W. G., MCGONIGLE, D. \& RUSSELL, A. E. 2004. Lost at sea: where is all the plastic? Science, 304(5672), 838.

VARGHESE, S. P., SOMVANSHI, V. S., JOHN, M. E. \& DALVI, R. S. 2013. Diet and consumption rates of common dolphinfsh, Coryphaena hippurus, in the eastern Arabian Sea. Journal of Applied Ichthyology, 29(5), 1022-1029.

VASKE JUNIOR, T. \& LESSA, R. 2004. Feeding habits of the common dolphinfish Coryphaena hippurus, in Northeastern Brazil's Exclusive Economic Zone. Arquivos de Ciências do Mar, 37(23), 131-138. 